\title{
Valorization of Agroindustrial Wastes as Biosorbent for the Removal of Textile Dyes from Aqueous Solutions
}

\author{
Elsa Contreras, ${ }^{1}$ Luisa Sepúlveda, ${ }^{1}$ and Carolyn Palma ${ }^{2}$ \\ ${ }^{1}$ Engineering Department, Santiago de Chile University, Avenida Libertador Bernardo O’Higgins 3363, Estación Central, \\ Santiago, CP 9160000, Chile \\ ${ }^{2}$ Chemical and Environmental Engineering Department, Federico Santa Maria Technical University, Avenida Vicuña Mackenna 3939, \\ San Joaquin, Santiago, CP 8940897, Chile \\ Correspondence should be addressed to Carolyn Palma, carolyn.palma@usm.cl
}

Received 31 October 2011; Revised 12 February 2012; Accepted 20 February 2012

Academic Editor: Licínio M. Gando-Ferreira

Copyright () 2012 Elsa Contreras et al. This is an open access article distributed under the Creative Commons Attribution License, which permits unrestricted use, distribution, and reproduction in any medium, provided the original work is properly cited.

\begin{abstract}
The goal is to determinate the technical feasibility of using agroindustrial wastes for adsorption of dyes. The $\mathrm{pH}_{\text {pzc }}$ of $\mathrm{Brewer}_{\mathrm{s}}$ spent grains and Orange peel is 5.3 and 3.5, respectively. The equilibrium isotherms of Basic Blue 41, Reactiive Black 5, and Acid Black 1 were carried out without $\mathrm{pHs}$ control which ranging between 4 and 5.5. The equilibrium concentrations for both adsorbents were fitted by the Freundlich and Langmuir models. The maximum adsorption capacity measured for Basic Blue 41, Reactive Black 5, and Acid Black 1 was 32.4, 22.3, and $19.8 \mathrm{mg} \mathrm{g}^{-1}$ for Brewer's spent grains; and 157, 62.6, and 45.5 for orange peel, respectively. The kinetic of process was fitted by the model of pseudo-second order. The constant rate for orange peel decreased to extend the initial concentration of dye increased, obtaining $4.08 * 10^{-3}-0.6 * 10^{-3}$ (Basic Blue 41), $2.98 * 10^{-3}-0.36 * 10^{-3}$ (Acid Black 1), and $3.40 * 10^{-3}-0.46 * 10^{-3} \mathrm{~g} \mathrm{mg}^{-1} \mathrm{~min}^{-1}$ (Reactive Black 5). The best removal efficiency was obtained in orange peel with values started from $63 \%$ to $20 \%$. Consequently, according the results obtained there are two positive effects, the reuse of agricultural wastes and its use as low-cost adsorbent of the dyes.
\end{abstract}

\section{Introduction}

The discharges of industrial wastewater containing dyes cause serious environmental problems, because their chemi$\mathrm{cal}$ structure gives them a persistent and recalcitrant nature. The released dye in water streams represents a risk of ecotoxicity and a potential danger of bioaccumulation. The transport of these contaminants through the food chain could even affect the human health. In the last two decades, the elimination of dyes from industrial textile waste waters has been one of the major challenges for researchers.

Adsorption has received special attention as a treatment for colorized wastewater because it produces an effluent of better quality and comparatively can become more effective and less expensive than conventional treatments. Granularactivated carbon has been designated by the Environmental Protection Agency (EPA) of USA as the best available technology (BAT) for organic chemicals removal. In fact, activated carbon adsorption is an effective treatment for removing varied organic contaminants and, particularly, textile dyes of different ionic nature $[1,2]$. However, the high volume of effluents generated in the textile wet process involves a high cost for regeneration of the activated carbon $[3,4]$.

On the other hand, as a consequence of industrial development, enormous quantities of agroindustrial wastes are generated annually that can be used like supplies for other processes in order to give added value. An alternative is the application in processes of wastewater treatment, promoting in this way a sustainable and environmentally friendly development. Recently, it has been evaluated the performance of different low-cost adsorbents, which can be used only once to avoid the costly stage of regeneration. These studies have included some types of biomass such as agroindustrial or forest wastes, namely, rice husk [5], coconut [6], spent coffee grounds, a byproducts of instant coffee industry [7], wood bark [8], among others. Although the removal efficiency that is achieved is less than using the activated carbon, the application to industrial scale can be economically attractive [9]. 
The adsorption capacity of these nonconventional adsorbents is due to the presence of biopolymers such as polysaccharides, lignin, hemicelluloses, and cellulose $[9,10]$. Brewers' spent grains, a lignocellulosic residual biomass from the brewing industry, are the major solid waste generated during the production process. The potential use of this waste as raw material in food industry, energy production, and biotechnological processes is currently being investigated [11]. Brewer's spent grains also have showed a significant potential as a biosorbent for application in the remediation of wastewater contaminated with metal and dye [12-14]. Besides other cellulose-based wastes such as banana peel have been used in the removal of dyes by adsorption $[15,16]$. The biomass residual of the citrus juice industry, peel, pulp, and seed represents $50 \%$ of the processed fruit mass. The efficient management of these agroindustrial wastes should not only promote but diversify its use. The utilization of citrus peel, orange, lemon, mandarin, and grapefruit, as a low-cost adsorbent, has recently been studied [17-20].

The aim of this research is to explore the technical feasibility of use the waste biomass such as Brewer's spent grains and orange peel for the biosorptive removal of textile dyes.

\section{Materials and Methods}

2.1. Agroindustrial Wastes. Brewer's spent grains (BSG,) were obtained from the local brewery. Orange peel (OP) from fruit purchased from a local market. These residual biomasses were dried at room temperature until they reached the equilibrium moisture content, around $10 \%(\mathrm{wt})$. The dry solids were crushed and later the mesh cut $[-18+60]$, which corresponds to particles larger than $0.25 \mathrm{~mm}$ and smaller than $1 \mathrm{~mm}$, was selected.

2.2. Dyes. The adsorbates evaluated in this study were the cationic dye Basic Blue 41 (C.I. 11105) and the anionic dyes, Acid Black 1 (C.I. 20470) and Reactive Black 5 (C.I. 20505). Methylene Blue (Basic Blue 9, C.I. 52015) was used for the determination of adsorptive properties of the agroindustrial wastes. Dyes are analytical grade supplied by Sigma Aldrich Co. The structure and properties of the dyes are shown in Table 1.

\subsection{Physical and Chemical Characterization}

Morphologic Characterization. It was realized by a Scanning Electron Microscopy analysis of the agroindustrial wastes, using JSPM-5410 Scanning Probe Microscope (JEOL Ltda) implemented with Anaglyph Maker 1.08 software. The images were obtained with a magnification of 1000x.

Surface Acidity and Basicity. The concentrations of acidic and basic sites in the adsorbents were determined by acidbase titration method proposed by Boehm [21]. 0.5 g of agroindustrial waste was contacted with $50 \mathrm{~mL}$ of $\mathrm{NaOH}$ $0.01 \mathrm{M}$ (acidity) or $50 \mathrm{~mL}$ of $0.1 \mathrm{M} \mathrm{HCl}$ (basicity) until the equilibrium was reached. An aliquot of $20 \mathrm{~mL}$ filtrate obtained from the contact assay $(24 \mathrm{~h})$ was then titrated with $0.01 \mathrm{M} \mathrm{HCl}$ or $0.1 \mathrm{M} \mathrm{NaOH}$ to neutralize the sodium hydroxide or hydrochloric acid in excess, respectively.
Point of Zero Charge ( $p H_{\mathrm{pzc}}$ ). 10, 7.5, 5, 2.5, and $1.25 \mathrm{~mL}$ of $0.1 \mathrm{M} \mathrm{HCl}$ were added to $1 \mathrm{~g}$ of agroindustrial wastes. Similarly, there was prepared another set of suspensions with $0.1 \mathrm{M} \mathrm{NaOH}$. Next, in all the flasks was added $5 \mathrm{~mL}$ of $\mathrm{KCl}$ $0.1 \mathrm{M}$ and was then completed with distilled water until $100 \mathrm{~mL}$. The flasks were maintained in a shaker with thermal control $\left(20^{\circ} \mathrm{C}, 150 \mathrm{rpm}\right)$ for $1 \mathrm{~h}$ and $\mathrm{pH}$ values $\left(\mathrm{pH}_{1}\right)$ were recorded. Subsequently $5 \mathrm{~mL}$ of $\mathrm{KCl} 1 \mathrm{M}$ was added to each sample, maintaining the agitation during $1 \mathrm{~h}$. The final $\mathrm{pH}$ of each sample $\left(\mathrm{pH}_{2}\right)$ was measured. The $\mathrm{pH}_{\mathrm{pzc}}$ for each waste was estimated as the final $\mathrm{pH}$ value, for which the difference between $\mathrm{pH}_{1}$ and $\mathrm{pH}_{2}$ was equal to zero [22].

pH of Adsorbent ( $p \mathrm{H}_{\mathrm{KCl} 1 \mathrm{M}}, \mathrm{pH}_{\mathrm{CaCl}_{2} 0.01 \mathrm{M}}$ ). $50 \mathrm{~mL}$ of solution $\mathrm{KCl} 0.1 \mathrm{M} \mathrm{KCl}$ or $\mathrm{CaCl}_{2} 0.01 \mathrm{M}$ was added in a flask containing $0.2 \mathrm{~g}$ of agroindustrial waste. The flasks were maintained in a shaker with thermal control $\left(25^{\circ} \mathrm{C}, 220 \mathrm{rpm}\right)$ for $2 \mathrm{~h}$; after that, the $\mathrm{pH}$ was measured for each suspension.

\subsection{Adsorptive Properties}

Methylene Blue Index. There was evaluated the adsorptive power of each waste by the Methylene Blue. Brewer's spent grains and Orange peel were place in contact with solution of Methylene Blue until equilibrium was reached. Solutions of dyes with an initial concentration between 50 and $500 \mathrm{mg} \mathrm{L}^{-1}$ and a dose of $3 \mathrm{~g}$ of Brewer's spent grains or $2 \mathrm{~g}$ of Orange peel per liter of solution were used. These suspensions were continuously stirred in a shaker with temperature controlled at $20^{\circ} \mathrm{C}$ for $24 \mathrm{~h}$. Finally the equilibrium concentration of dye in the solution was determined. The experimental equilibrium concentrations in the liquid and solid phase were correlated using the Langmuir isotherm model.

\subsection{Biosorption of Dyes}

Adsorption Equilibrium of Dyes. $100 \mathrm{~mL}$ of solutions with different initial concentrations in the range $50-500 \mathrm{mg} \mathrm{L}^{-1}$ were place in contact with $0.2 \mathrm{~g}$ of BSG or OP in Erlenmeyer flasks which were kept with agitation and temperature control $\left(200 \mathrm{rpm}, 25 \pm 2^{\circ} \mathrm{C}\right)$ until the equilibrium was achieved. Finally, the equilibrium concentration of dye in the solution was determined.

Adsorption Kinetic of Dyes. $100 \mathrm{~mL}$ of dye solution with different initial concentrations $\left(50,200\right.$, and $500 \mathrm{mg} \mathrm{L}^{-1}$ ) was placed in contact with $0.2 \mathrm{~g}$ of agroindustrial waste (BSG and $\mathrm{OP})$, in Erlenmeyer flasks which were agitated and kept with controlled temperature $\left(200 \mathrm{rpm}, 25 \pm 2^{\circ} \mathrm{C}\right)$. The dynamic process was identified through the evolution of residual concentration of dye in solution at different contact times, until the variation between two successive measurements was not significant.

pH of Adsorbent. $50 \mathrm{~mL}$ of solution $\mathrm{KCl} 1 \mathrm{M}$ or of $\mathrm{CaCl}_{2}$ $0.01 \mathrm{M}$ was added to $0.2 \mathrm{~g}$ of agroindustrial wastes, and then, the flasks were maintained in a shaker with thermal control $\left(25^{\circ} \mathrm{C}, 220 \mathrm{rpm}\right)$ for $2 \mathrm{~h}$. Finally the $\mathrm{pH}$ of each suspension was measured. 
TABLE 1: Structure and properties of dyes.

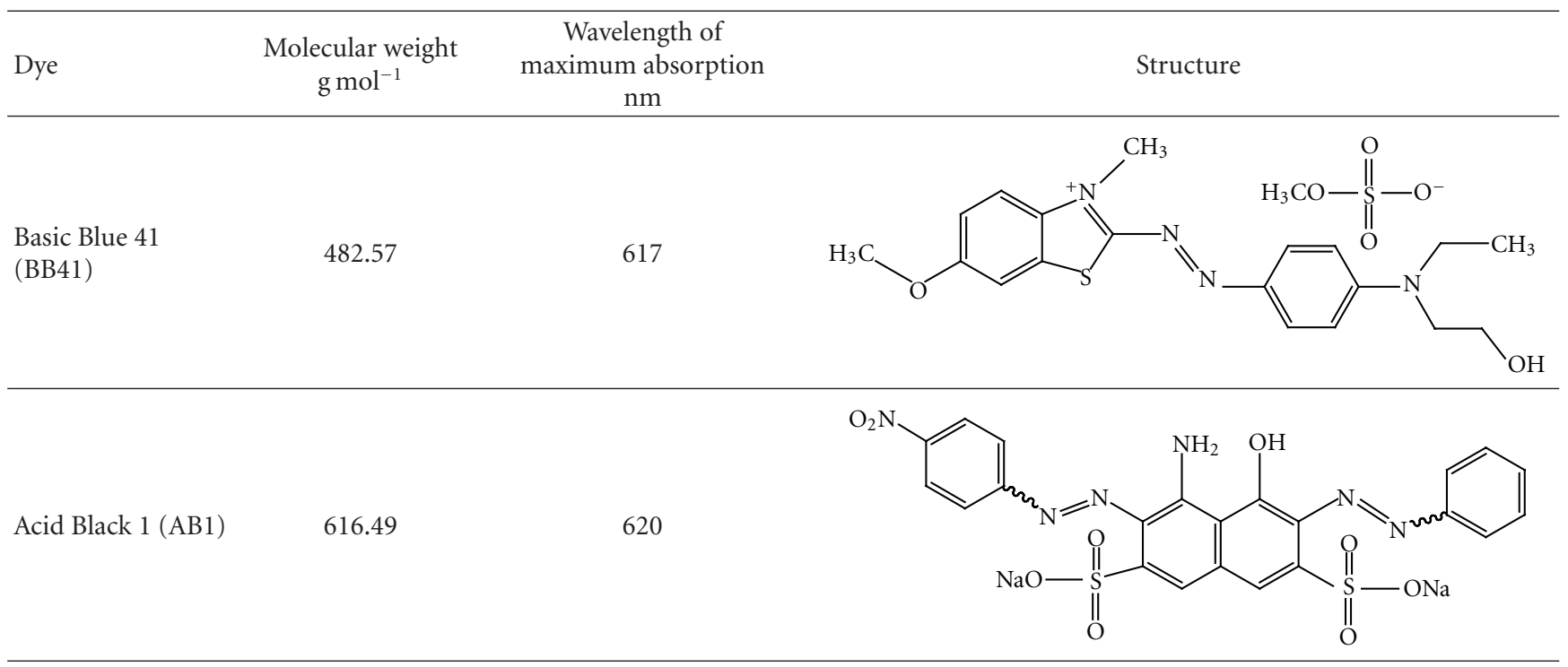

Reactive Black 5 (RB5)
991.82

597<smiles>CCCOS(=O)(=O)O[Na]</smiles><smiles>[Y19]OS(=O)(=O)c1cccc(O)c1N=Nc1ccc(S(=O)(=O)O)cc1</smiles><smiles>CCOS(=O)(=O)OC</smiles>
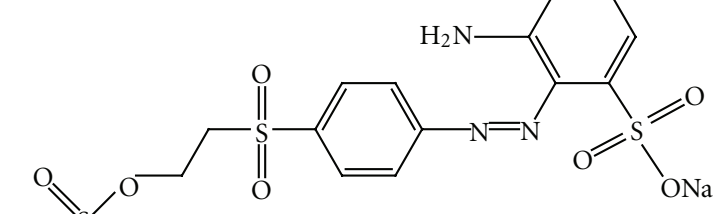<smiles>CN(C)c1ccc2nc3ccc(N(C)[As])cc3c(Cl)c2c1</smiles>

Basic Blue 9 (Methylene Blue)

2.6. Parameter Estimation of Equilibrium and Kinetic Model. The function was fitted by the method of Nonlinear-LeastSquares using the algorithm of Levenberg-Marquardt that minimizes the sum of the squares of the errors between the data points and the function. The statistical indicators used to assess convergence were the determination coefficient $\left(R^{2}\right)$ and the quadratic sum of the residues $\left(\sum e^{2}\right)$ by

$$
\begin{gathered}
R^{2}=\frac{\sum_{1}^{n}\left(q_{\exp }-\bar{q}\right)^{2}-\sum_{1}^{n}\left(q_{\exp }-q_{\text {model }}\right)^{2}}{\sum_{1}^{n}\left(q_{\exp }-\bar{q}\right)^{2}}, \\
\sum e^{2}=\sum_{1}^{n}\left(q_{\exp }-q_{\text {model }}\right)^{2} .
\end{gathered}
$$

The resolution of algorithm was realized by Statistic 7.0 software.

2.7. Analytical Assays. The samples were centrifuged and the residual dye concentration in the supernatant was determined by measuring absorbance at maximum wavelength of each dye in a Helios Gamma UV-Vis spectrophotometer (UK).

The adsorption capacity was determined using mass balance, applied to solid and liquid phases in accordance with the following:

$$
q=\frac{V\left(C_{0}-C\right)}{m}
$$




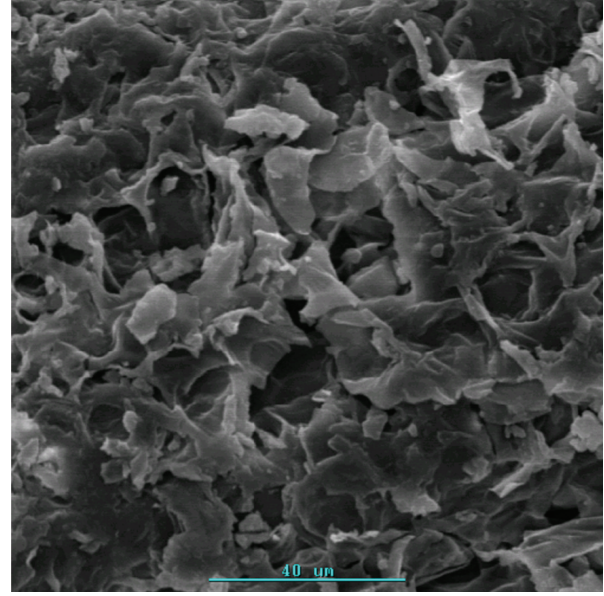

Accelerating voltage: $20 \mathrm{Kev}$

Resolution: 1024x1024

Magnification: 1000

Pixel size: 0.118515 microns

(a) Brewer's spent grains

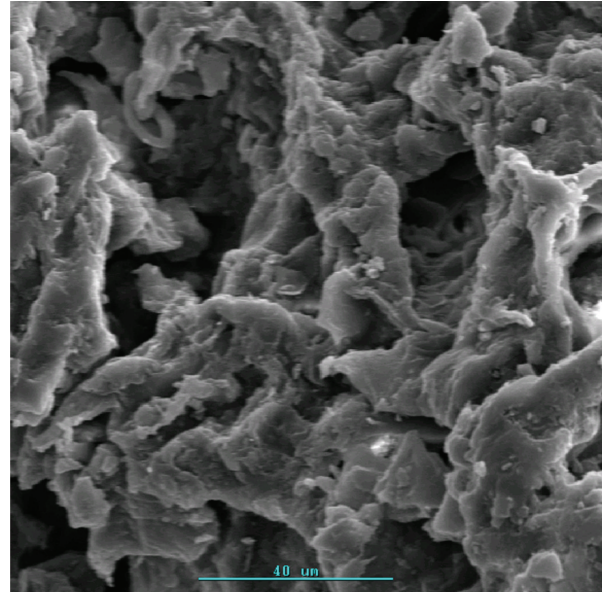

Accelerating voltage: $20 \mathrm{Kev}$

Resolution: $1024 \times 1024$

Magnification: 1000

Pixel size: 0.118515 microns

(b) Orange peel

FIGURE 1: Analysis SEM of agroindustrial wastes.

TABLE 2: Chemical and physical characterization of adsorbents.

\begin{tabular}{lcr}
\hline & Brewer's spent grains & Orange peel \\
\hline Point of zero charge & 5.3 & 3.5 \\
$\mathrm{pH}_{\text {water }}$ & - & $4.98 \pm 0.00$ \\
$\mathrm{pH}_{\mathrm{KCl} 1.0 \mathrm{M}}$ & $4.80 \pm 0.08$ & $4.21 \pm 0.04$ \\
$\mathrm{pH}_{\mathrm{CaCl}_{2} 0.01 \mathrm{M}}$ & $4.55 \pm 0.10$ & $4.67 \pm 0.01$ \\
Surface acidity $(\mathrm{NaOH}) \mathrm{mmol} \mathrm{g}^{-1}$ & $3.37 \pm 0.02$ & $2.58 \pm 0.19$ \\
Surface basicity $(\mathrm{HCl}) \mathrm{mmol} \mathrm{g}^{-1}$ & $3.16 \pm 0.01$ & $0.25 \pm 0.07$ \\
Methylene Blue Index mg g & 64.9 & 178.7 \\
\hline
\end{tabular}

where $q$ is the adsorption capacity $\left(\mathrm{mg} \mathrm{g}^{-1}\right), V$ is the solution volume $(\mathrm{L}), C_{0}$ is the initial dye concentration $\left(\mathrm{mg} \mathrm{L}^{-1}\right)$, and $C$ is the dye concentration on time $\left(\mathrm{mg} \mathrm{L}^{-1}\right)$.

\section{Results and Discussion}

3.1. Physical and Chemical Characterization of Adsorbent. The surface morphology of the particle wastes, Brewer's spent grains (Figure 1(a)) and Orange peel (Figure 1(b)), was analyzed by scanning electron microscopy. The micrographs revealed that the particles of Brewer's spent grains showed a rigid structure and higher density of macropores, while the particles of Orange peel are rather nonporous. The particles of both wastes have irregular shape and the textures of its surface are microrough.

The acid-base behavior of functional groups of the adsorbent surface plays a crucial role in interactions occurring during the process. The surface charge of the agroindustrial waste can be explained in terms of its $\mathrm{pH}_{\mathrm{pzc}}$ value and of the concentration of acidic and basic sites at the particles surface. The acidic characteristic of activated carbon surface, for example, is caused by the presence of carboxyl groups, lactones, and of phenolic hydroxyl groups [21]. Similarly the cellulose, one of the major components of agroindustrial waste, has a predominantly acid character because the hydrogen atoms of the hydroxyl groups act as electron acceptors [23]. Furthermore the principal components of the Orange peel, addition of the soluble material (41\%) and other minor compounds, are cellulose $(16 \%)$, hemicellulose $(13.8 \%)$, pectin $(14 \%)$, and protein $(7.9 \%)[24,25]$. These components contain carboxyl and hydroxyl groups, causing the acid behavior of its surface. Brewer's spent grains contain principally cellulose (16-25\%), hemi cellulose (30\%), lignin (7-27\%), and protein (2.4-24\%), its acid character being determined principally by phenolic hydroxyl groups present in the lignin [12]. The basic behavior of BSG is caused by the amine groups present in the protein.

Table 2 shows the value of $\mathrm{pH}_{\mathrm{pzc}}$ and the basicity and acidity surface of Brewer's spent grains and Orange peel. The magnitude of these properties agrees with the values presented by other authors for this same type of wastes [25]. It can be seen that Orange peel has acid character higher than 


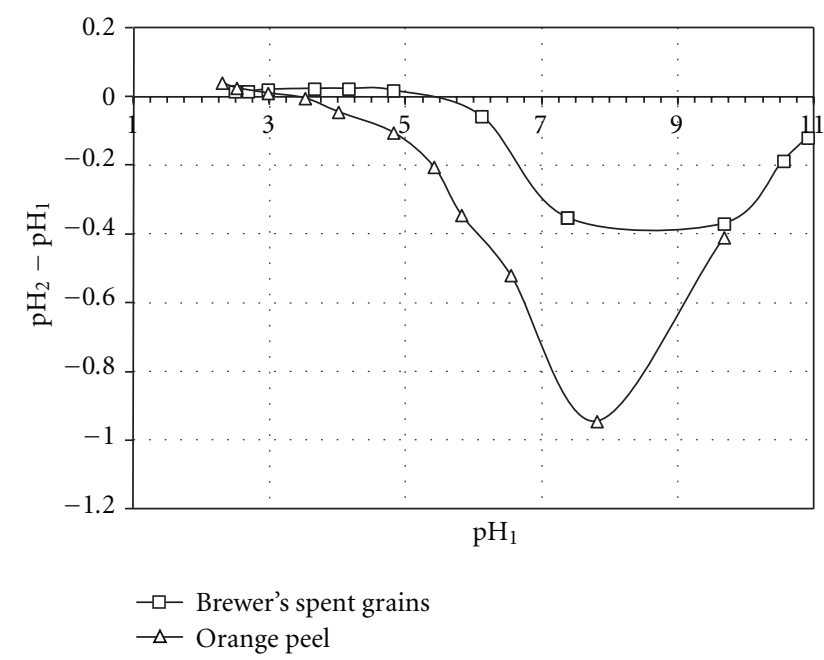

FIgURE 2: Zero charge point of agroindustrial wastes.

Brewer's spent grains. The acidic sites concentration of OP is 10 times higher than the sites with basic behavior while in BSG this relation is scarcely higher than one.

Consequently the zero-charge point of $\mathrm{OP}$ is less than BSG and corresponds to $\mathrm{pH}$ value of 3.5 (Figure 2). Then OP is classified as a biosorbent of acid type so that, when the $\mathrm{pH}$ of a solution is higher than the value of $\mathrm{pH}_{\mathrm{pzc}}$, the acid groups of pectin (galacturonic acid) are in the deprotonated form. Under this condition OP interacts preferentially with cationic species.

The complex structure of the agrowaste has similitude with the soil organic matter; that is, their functional groups contain electron pairs nonbinding that can interact with the protons present in the liquid phase in equilibrium; therefore in this case, the evaluation of surface acidity by measurement of $\mathrm{pH}$ can also show any fluctuation. This effect can be evaluated measuring the $\mathrm{pH}$ of suspensions in different saline solutions. The protocols of characterization of soils indicate to use $\mathrm{KCl} 1 \mathrm{M}$ and $\mathrm{CaCl}_{2} \quad 0.01 \mathrm{M}$ [26]. The results of $\mathrm{pH}$ drop between both measures $\left(\mathrm{pH}_{\text {water }}-\mathrm{pH}_{\mathrm{KCl} \mathrm{1.0} \mathrm{M}}\right)=$ 0.77 and $\left(\mathrm{pH}_{\text {water }}-\mathrm{pH}_{\mathrm{CaCl}_{2} 0.01 \mathrm{M}}\right)=0.31$, which were obtained for OP confirming that this is a biosorbent with strongly acidic character, coincide with the low value of $\mathrm{pH}_{\mathrm{pzc}}$ (Table 2). In the first measurement, the $\mathrm{pH}$ drop is a consequence of the replacement of the hydrogen ions of the surface functional groups by the potassium from the solution, causing a decrease in the $\mathrm{pH}$. Since $\mathrm{CaCl}_{2}$ is a weak base, it causes an impoverishment in hydroxyl ions whose, although has an effect similar to increased of protons produced in the previous case, magnitude is lower.

The concentration of surface groups present in this type of lignocellulosic adsorbents is significantly higher than that found in commercial activated carbons. For example, commercial activated carbon F-400 (Calgon Carbon) exhibits a functional group concentration between 0.4 and $0.6 \mathrm{meq} \mathrm{g}^{-1}$, with a slightly basic feature, which provides a zero charge point between 7.3 and $7.9[2,27]$.
The quality of adsorbents, activated carbons particularly, is evaluated in terms of their adsorptive power and superficial area. The Methylene Blue Index that quantifies the amount of dye necessary to cover the total surface of the particles is widely used to evaluate the active carbon and other alternative adsorbents. The nonpolar nature of the Methylene Blue molecule and its molecular size (8.4 $\AA$ ) (Table 1) suggests that the adsorption occurs at the macropores and mesopores.

The Methylene Blue Index of Brewer's spent grains and the Orange peel is shown in Table 2. The values obtained confirm the observations of morphological analysis; that is, BSG has a mesoporous structure. These results are comparable with the Index of the active carbons prepared from sugarcane bagasse and coconut shell (79.6 and $10.5 \mathrm{mg} \mathrm{g}^{-1}$, resp.) and less than the value of cellulose materials such as cotton $[28,29]$

The estimation of specific surfaces of BSG and OP using the adsorption of Methylene Blue was $206.2 \mathrm{~m}^{2} \mathrm{~g}^{-1}$ and $567.3 \mathrm{~m}^{2} \mathrm{~g}^{-1}$, respectively. Both values obtained for other low-cost biosorbents, such as peanut shells, olive stones, bamboo cane, and date stones, have the same order of magnitude (368-394 $\left.\mathrm{m}^{2} \mathrm{~g}^{-1}\right)$ [30].

3.2. Equilibrium Isotherm. The most widely models used to describe the adsorption equilibrium are the Langmuir [31] and Freundlich [32] isotherms, which are shown in (3) and (4), respectively:

$$
q_{e}=\frac{q_{\max } b C_{e}}{\left(1+b C_{e}\right)},
$$

where $q_{\max }$ is the maximum adsorption capacity (complete monolayer) $\left(\mathrm{mg} \mathrm{g}^{-1}\right)$ and $\mathrm{b}$ is associated with interaction energy between absorbate and adsorbent $\left(\mathrm{L} \mathrm{g}^{-1}\right)$ :

$$
q_{e}=k_{F} C_{e}^{1 / n}
$$

where $k_{F}$ is the equilibrium constant $\left(\mathrm{mgg}^{-1}\left(\mathrm{~L} \mathrm{mg}^{-1}\right)^{1 / n}\right)$ and $n$ is a parameter associated with the affinity between adsorbate and adsorbent.

Figures 3 and 4 show the dependence between equilibrium concentrations of both phases for adsorption of BB41, $\mathrm{RB} 5$, and $\mathrm{AB} 1$ dyes on Brewer's spent grains and Orange peel, respectively.

Additionally, the parameters and their standard deviations, obtained by fitting the Langmuir and Freundlich models, are shown in Tables 3 and 4. The experimental data adsorption equilibrium of dyes on BSG can be interpreted adequately by the Freundlich model $\left(R^{2}>0.96\right)$, whereas with the Langmuir model a better quality of fit was obtained for the BB41 and RB5 adsorption on Orange peel $\left(R^{2}>\right.$ 0.97). The values of maximum adsorption capacity of the dyes on OP are higher than BSG, 5, 2.5, and 2-fold for BB41, $\mathrm{RB} 5$, and $\mathrm{AB} 1$, respectively.

The magnitudes of $b$ parameters of the Langmuir isotherm indicate that the interaction energies between the dyes and adsorption sites of the BSG, are greater than those obtained with BSG (Table 3 ), probably due to the acidic nature of this latter provided by the carboxylic functional groups. In the case of adsorption of RB5 on OP this 
TABLE 3: Langmuir model parameters.

\begin{tabular}{lcccccccc}
\hline Dye & \multicolumn{3}{c}{ Brewer's spent grains } & \multicolumn{3}{c}{ Orange peel } \\
& $q_{\max }\left(\mathrm{mg} \mathrm{g}^{-1}\right)$ & $b\left(\mathrm{~L} \mathrm{mg}^{-1}\right)$ & $R^{2}$ & $\sum e^{2}$ & $q_{\max }\left(\mathrm{mgg}^{-1}\right)$ & $b\left(\mathrm{~L} \mathrm{mg}^{-1}\right)$ & $R^{2}$ & $\sum e^{2}$ \\
\hline BB41 & $32.4 \pm 2.3$ & $0.021 \pm 0.007$ & 0.772 & 66.5 & $157.2 \pm 4.2$ & $0.021 \pm 0.002$ & 0.992 & 108.4 \\
RB5 & $22.3 \pm 1.9$ & $0.0077 \pm 0.0019$ & 0.911 & 12.2 & $62.6 \pm 14.8$ & $0.0012 \pm 0.0004$ & 0.977 & 8.2 \\
AB1 & $19.8 \pm 0.3$ & $0.019 \pm 0.001$ & 0.985 & 1.26 & $45.3 \pm 7.5$ & $0.0086 \pm 0.0042$ & 0.737 & 102.2 \\
\hline
\end{tabular}

TABLE 4: Freundlich model parameters.

\begin{tabular}{lcccccccc}
\hline \multirow{2}{*}{ Dye } & \multicolumn{3}{c}{ Brewer's spent grains } & \multicolumn{3}{c}{ Orange peel } \\
& $k_{F}\left(\mathrm{mg} \mathrm{g}^{-1}\right)\left(\mathrm{mg} \mathrm{L}^{-1}\right)^{-1 / n}$ & $N$ & $R^{2}$ & $\sum e^{2}$ & $k_{F}\left(\mathrm{mg} \mathrm{g}^{-1}\right)\left(\mathrm{mg} \mathrm{L}^{-1}\right)^{-1 / n}$ & $n$ & $R^{2}$ & $\sum e^{2}$ \\
\hline BB41 & $5.54 \pm 0.70$ & $3.51 \pm 0.28$ & 0.962 & 11.4 & $15.72 \pm 3.06$ & $2.50 \pm 0.25$ & 0.951 & 625.9 \\
RB5 & $1.46 \pm 0.26$ & $2.42 \pm 0.19$ & 0.967 & 4.6 & $0.21 \pm 0.06$ & $1.31 \pm 0.09$ & 0.980 & 7.0 \\
AB1 & $3.67 \pm 0.43$ & $3.77 \pm 0.30$ & 0.962 & 3.4 & $3.08 \pm 1.39$ & $2.42 \pm 0.48$ & 0.822 & 130.3 \\
\hline
\end{tabular}

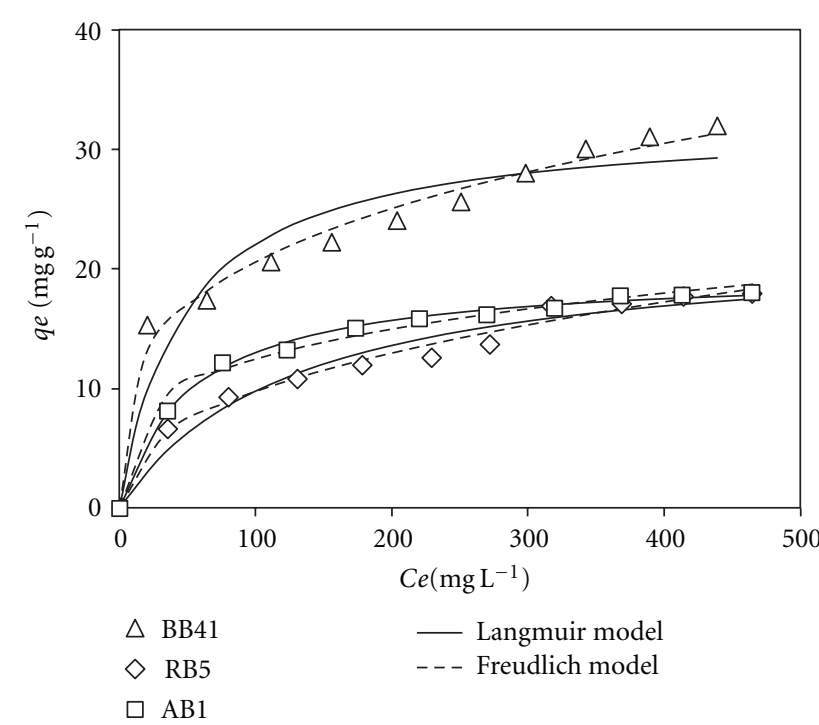

Figure 3: Adsorption isotherms of dyes on Brewer's spent grains. Experimental conditions: temperature: $25^{\circ} \mathrm{C} ; \mathrm{pH}$ (natural): 4.0 (BB41), 5.0 (RB5), 5.3 (AB1): particle size; 0.25-1.00 mm.

parameter is 20 times lower with respect to the one obtained for the basic dye, whereby the isotherm is almost linear. The partition constant was estimated in 0.0528 with a correlation coefficient of 0.96 . This means that the removal of dye by OP is only caused by a phenomenon of partition and the interactions occur primarily with adsorption sites existing on the outer surface of this waste. This result also is originated for the lower hydrophobicity and higher charge density that has RB5 in respect to the other dyes.

In another study performed with the orange peel, reported similar results for the adsorption of basic and acid dyes. The maximum adsorption capacity of acid dyes is between 40 and $65 \mathrm{mg} \mathrm{g}^{-1}$, and the magnitude of the interaction parameters is equal to that obtained in this study (0.001-0.008 $\mathrm{L} \mathrm{mg}^{-1}$ ) [33]. On the other hand, the maximum adsorption capacity of malachite green on OP was determined in $483 \mathrm{mgg}^{-1}$ [34]. Similarly, the maximum

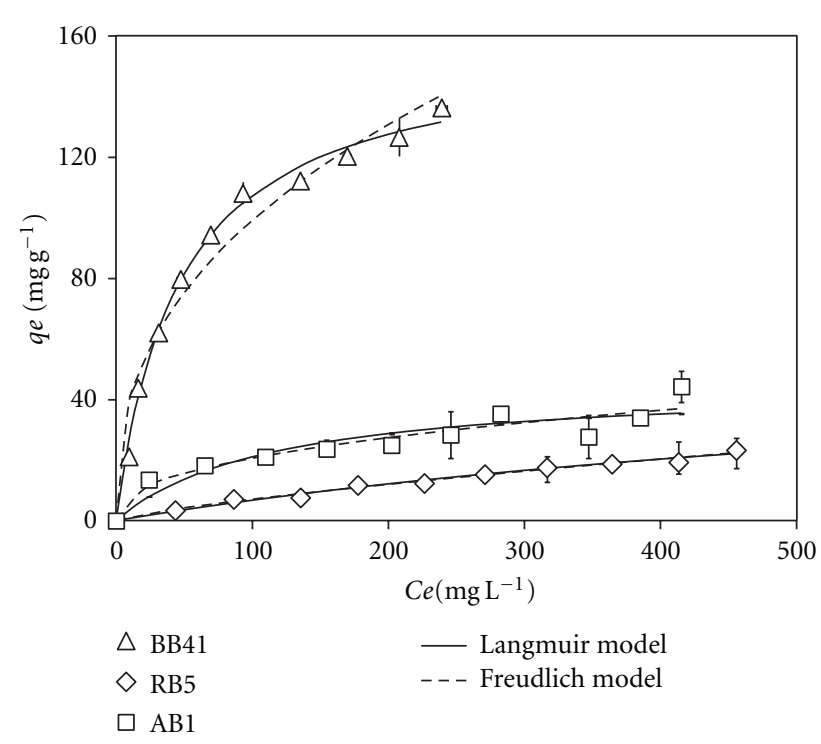

FIgure 4: Adsorption isotherms of dyes on Orange peel. Experimental conditions: temperature $25^{\circ} \mathrm{C}: \mathrm{pH}$ (natural): 4.4 (BB41), 5.5 (RB5), 4.9 (AB1); particle size: $0.25-1.00 \mathrm{~mm}$.

adsorption capacity reported for the acid dyes uptake (Acid Yellow 17 and Acid Blue 25) on Brewer's spent grains is equivalent to that obtained in this work [35].

Although both adsorbents have an adsorption capacity of dyes, of different ionic behavior, significantly lower than those reported for commercial activated carbon and that their interaction energies are also lower, they have a higher density of functional groups $[1,2,26,36]$. In particular it has been reported that the adsorption capacity of RB5 by activated carbon is $175 \mathrm{mg} \mathrm{g}^{-1}$ [37]. Despite this, the adsorption capacities obtained with the Orange peel indicate that its use in the removal of dyes from waste water can be an attractive option, especially for those of basic type.

3.3. Kinetic Modeling. The pseudo-second-order rate expression has been used to describe adsorption that involves valence forces through electrons shared or exchanged between 


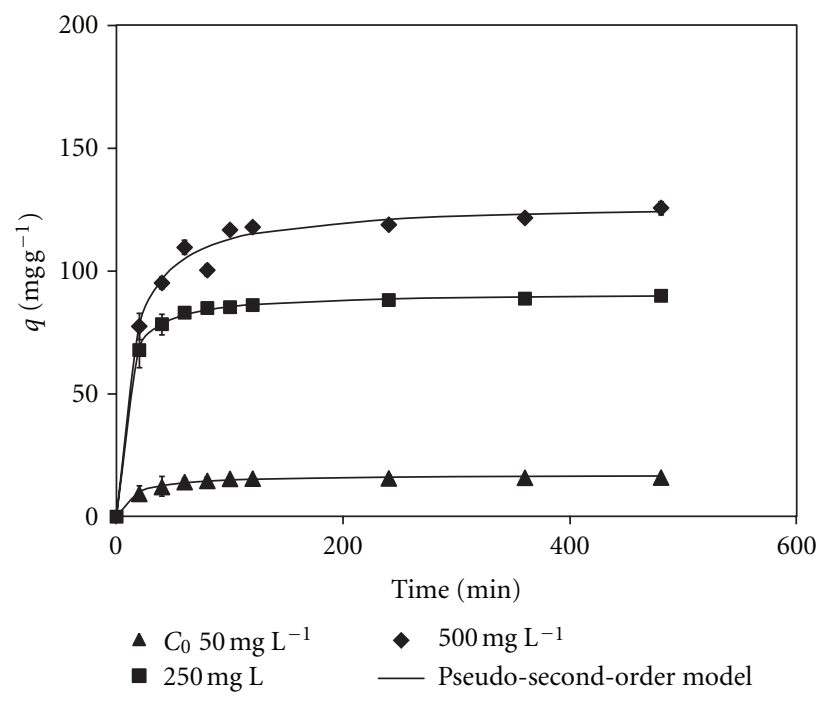

(a) BB41 adsorption on OP

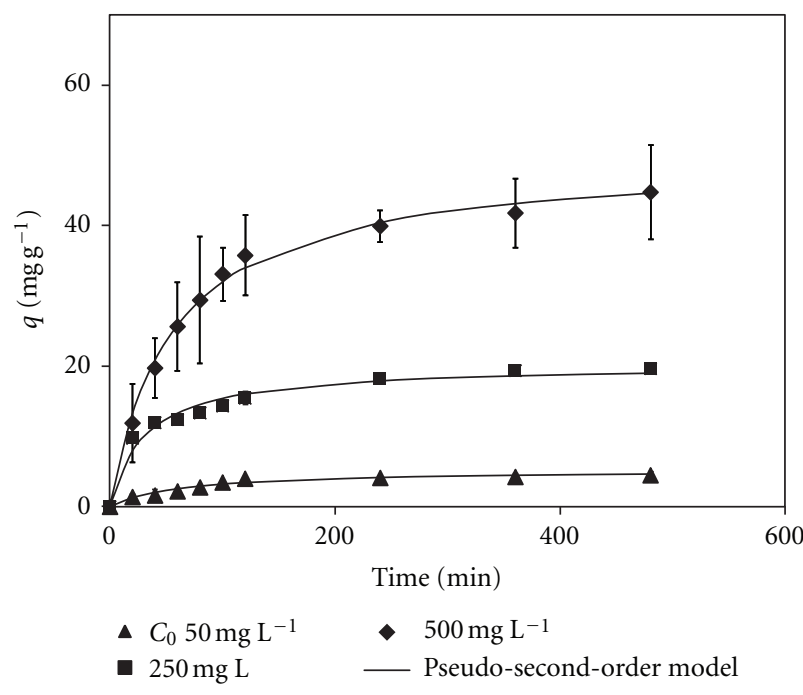

(c) $\mathrm{AB} 1$ adsorption on $\mathrm{OP}$

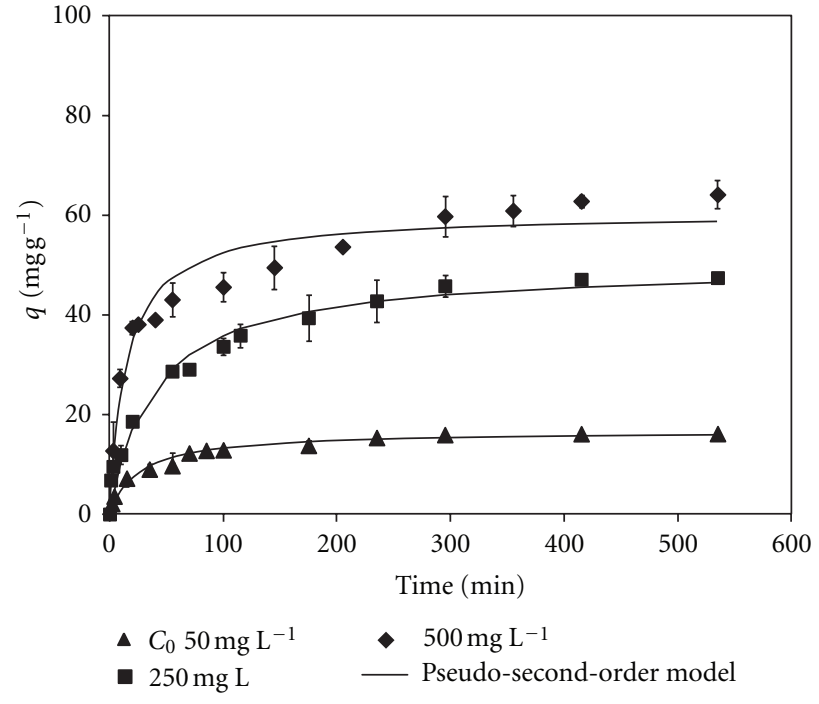

(b) BB41 adsorption on BSG

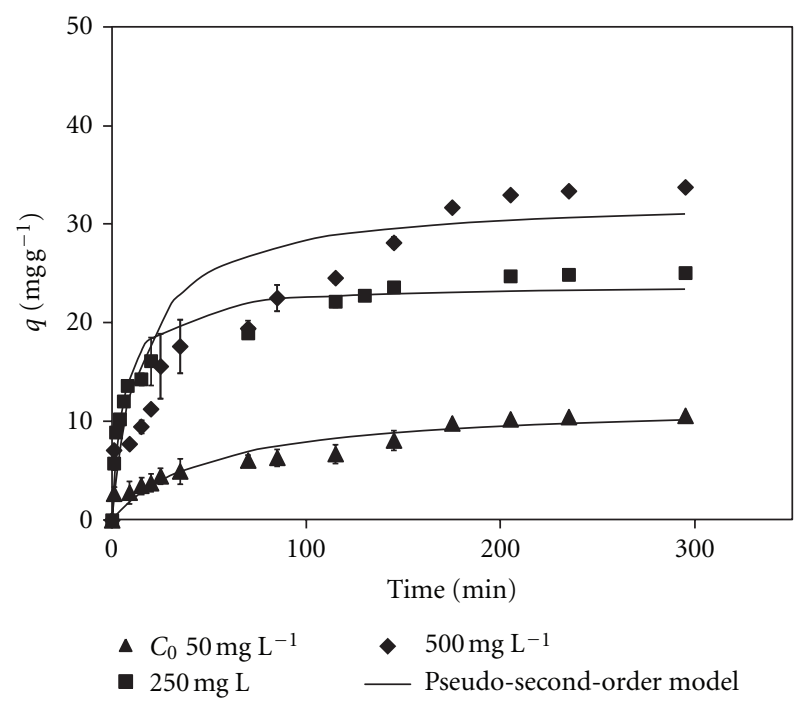

(d) AB1 adsorption on BSG

FIgURE 5: Kinetic modeling of dye adsorption on agroindustrial wastes.

the adsorbent and adsorbate, such as covalent interactions and ion exchange [38]. Recently this kinetic model (5) has been successfully applied to the adsorption of pollutants from aqueous solutions:

$$
\frac{d q}{d t}=k_{2}\left(q_{e}-q\right)^{2}
$$

where $k_{2}$ is the pseudo-second-order rate constant $\left(\mathrm{g} \mathrm{mg}^{-1}\right.$ $\left.\min ^{-1}\right), q_{\mathrm{e}}$ is the amount of dye adsorbed at equilibrium $\left(\mathrm{mg} \mathrm{g}^{-1}\right)$, and $\mathrm{q}$ is the amount of dye adsorbed at time $\mathrm{t}$ $\left(\mathrm{mg} \mathrm{g}^{-1}\right)$.

Equation (6) is obtained by integrating (5) using the boundary conditions $t=0$ to $t=t$ and $q=0$ to $q=q$ :

$$
q=q_{e}\left[1-\frac{1}{\left(1+k_{2} q_{e} t\right)}\right] \text {. }
$$

The progress curve of the adsorption capacity (6) was properly interpreted by the pseudo-second-order model (Figure 5); the coefficients of determination are in the range $0.90-0.99$. The results indicate that the adsorption capacity was increasing to the extent that the initial concentration of dye was higher because the driving force has been enhanced. However, for the adsorption of dyes onto BSG using the greater initial concentration $\left(500 \mathrm{mg} \mathrm{L}^{-1}\right)$, the intraparticle diffusion restriction appears very early, which is consistent with the porous morphology of this adsorbent. The diffusive control intraparticle is more notable to the extent that the molecular weight increases. Figures 5(b) and 5(d) show the adsorption of BB41 and AB1 whose ratio of molecular weights is $1: 1.3$ (Table 1 ). Therefore this effect is manifested most significantly with the dye RB5. 
TABle 5: Parameters of pseudo second order model.

\begin{tabular}{|c|c|c|c|c|c|}
\hline \multicolumn{6}{|c|}{ Basic Blue 41} \\
\hline$C_{0}\left(\mathrm{mg} \mathrm{L}^{-1}\right)$ & & $q_{e}\left(\mathrm{mgg}^{-1}\right)$ & $k_{2} * 10^{3}\left(\mathrm{~g} \mathrm{mg}^{-1} \mathrm{~min}^{-1}\right)$ & $R^{2}$ & $\sum e^{2}$ \\
\hline \multirow{2}{*}{50} & BSG & $16.67 \pm 0.51$ & $2.30 \pm 0.39$ & 0.979 & 8.23 \\
\hline & OP & $16.87 \pm 0.29$ & $4.08 \pm 0.51$ & 0.992 & 1.75 \\
\hline \multirow{2}{*}{250} & BSG & $49.88 \pm 2.06$ & $0.51 \pm 0.11$ & 0.972 & 97.03 \\
\hline & $\mathrm{OP}$ & $91.15 \pm 0.33$ & $1.67 \pm 0.68$ & 0.999 & 2.89 \\
\hline \multirow{2}{*}{500} & BSG & $60.38 \pm 2.09$ & $1.08 \pm 0.23$ & 0.952 & 225.96 \\
\hline & $\mathrm{OP}$ & $127.46 \pm 2.60$ & $0.61 \pm 0.09$ & 0.989 & 143.81 \\
\hline \multicolumn{6}{|c|}{ Acid Black 1} \\
\hline \multirow{2}{*}{50} & BSG & $11.85 \pm 1.02$ & $1.68 \pm 0.59$ & 0.904 & 14.52 \\
\hline & $\mathrm{OP}$ & $5.21 \pm 0.33$ & $2.98 \pm 0.76$ & 0.961 & 0.78 \\
\hline \multirow{2}{*}{250} & BSG & $23.87 \pm 0.80$ & $6.97 \pm 1.35$ & 0.948 & 44.95 \\
\hline & $\mathrm{OP}$ & $20.26 \pm 0.82$ & $1.57 \pm 0.32$ & 0.971 & 8.66 \\
\hline \multirow{2}{*}{500} & BSG & $32.65 \pm 1.77$ & $2.04 \pm 0.62$ & 0.920 & 135.85 \\
\hline & OP & $49.85 \pm 1.05$ & $0.36 \pm 0.03$ & 0.995 & 9.15 \\
\hline \multicolumn{6}{|c|}{ Reactive Black 5} \\
\hline \multirow{2}{*}{50} & BSG & $10.07 \pm 0.46$ & $7.30 \pm 0.13$ & 0.990 & 1.18 \\
\hline & OP & $3.18 \pm 0.10$ & $3.40 \pm 0.39$ & 0.993 & 0.05 \\
\hline \multirow{2}{*}{250} & BSG & $17.38 \pm 0.61$ & $0.62 \pm 0.09$ & 0.991 & 3.32 \\
\hline & $\mathrm{OP}$ & $20.03 \pm 0.34$ & $1.87 \pm 0.17$ & 0.994 & 1.67 \\
\hline \multirow{2}{*}{500} & BSG & $97.5 \pm 35.10$ & $0.01 \pm 0,00$ & 0.975 & 81.73 \\
\hline & $\mathrm{OP}$ & $40.32 \pm 2.37$ & $0.46 \pm 0.11$ & 0.958 & 47.89 \\
\hline
\end{tabular}

The decay curves of RB5 concentration $\left(C / C_{0}\right.$ against $\left.t\right)$ obtained for adsorption on OP at different initial concentrations of dye, overlap. This result indicates the absence of diffusion intraparticle, and therefore, the process is governed only by the external mass transfer. The high molecular weight of RB5 and the structure nonporous of OP are the causes of this behavior.

The parameters of pseudo-second-order model, $q_{e}$ and $k_{2}$, and their standard deviations are shown in Table 5. The equilibrium adsorption capacity of OP was higher than BSG; specifically the values for $\mathrm{BB} 41, \mathrm{RB} 5$ and $\mathrm{AB} 1$, are respectively, 6-, 2.5- and 2-fold higher. The equilibrium capacities for both adsorbents increase as the initial dye concentration is increased. The kinetic parameter $\mathrm{k}_{2}$, obtained for Orange peel, decreases steadily to the extent that the initial dye concentration increased, while for BSG it does not show a clear trend as a consequence of the restrictions imposed by the diffusion intraparticle.

\section{Conclusion}

The present study shows that the agroindustrial wastes biomass such Orange peel and Brewer's spent grains has significant potential as biosorbents for the removal of basic dyes from its aqueous solution, because their surfaces are predominantly negatively charged. The results indicated that the Orange peel presented a higher maximum capacity of adsorption than Brewer's spent grains for the cationic dye, Basic Blue 41, as well as for the anionic dyes, Acid Black 1, and Reactive Black 5.

\section{Acknowledgment}

This work was funded by Chilean Agency Fondecyt, Project 1090098.

\section{References}

[1] P. C. C. Faria, J. J. M. Orfão, and M. F. R. Pereira, "Adsorption of anionic and cationic dyes on activated carbons with different surface chemistries," Water Research, vol. 38, no. 8, pp. 2043-2052, 2004.

[2] Y. S. Al-Degs, M. I. El-Barghouthi, A. H. El-Sheikh, and G. M. Walker, "Effect of solution $\mathrm{pH}$, ionic strength, and temperature on adsorption behavior of reactive dyes on activated carbon," Dyes and Pigments, vol. 77, no. 1, pp. 16-23, 2008.

[3] R. Kant and V. K. Rattan, "Adsorption of dye Green B from a textile industry effluent using two different samples of activated carbon by static batch method and continuous process," Indian Journal of Chemical Technology, vol. 16, no. 3, pp. 240-244, 2009.

[4] Y. S. Al-Degs, M. A. M. Khraisheh, S. J. Allen, and M. N. Ahmad, "Adsorption characteristics of reactive dyes in columns of activated carbon," Journal of Hazardous Materials, vol. 165, no. 1-3, pp. 944-949, 2009.

[5] V. Vadivelan and K. Vasanth Kumar, "Equilibrium, kinetics, mechanism, and process design for the sorption of methylene blue onto rice husk," Journal of Colloid and Interface Science, vol. 286, no. 1, pp. 90-100, 2005.

[6] B. H. Hameed, D. K. Mahmoud, and A. L. Ahmad, "Equilibrium modeling and kinetic studies on the adsorption of basic dye by a low-cost adsorbent: coconut (Cocos nucifera) bunch 
waste," Journal of Hazardous Materials, vol. 158, no. 1, pp. 6572, 2008.

[7] A. S. Franca, L. S. Oliveira, and M. E. Ferreira, "Kinetics and equilibrium studies of methylene blue adsorption by spent coffee grounds," Desalination, vol. 249, no. 1, pp. 267-272, 2009.

[8] S. Patil, S. Renukdas, and N. Patel, "Removal of methylene blue, a basic dye from aqueous solutions by adsorption using teak tree (Tectona grandis) bark powder," International Journal of Environmental Sciences, vol. 1, no. 5, pp. 711-726, 2011.

[9] V. K. Gupta and Suhas, "Application of low-cost adsorbents for dye removal-a review," Journal of Environmental Management, vol. 90, no. 8, pp. 2313-2342, 2009.

[10] G. Y. S. Mtui, "Recent advances in pretreatment of lignocellulosic wastes and production of value added products," African Journal of Biotechnology, vol. 8, no. 8, pp. 1398-1415, 2009.

[11] S. I. Mussatto, G. Dragone, and I. C. Roberto, "Brewers' spent grain: generation, characteristics and potential applications," Journal of Cereal Science, vol. 43, no. 1, pp. 1-14, 2006.

[12] S. Aliyu and M. Bala, "Brewer's spent grain: a review of its potentials and applications," African Journal of Biotechnology, vol. 10, no. 3, pp. 324-331, 2011.

[13] V. Jaikumar, "Biosorption of acid yellow by spent brewery grains in a batch system: equilibrium and kinetic modelling," International Journal of Biology, vol. 1, no. 1, pp. 21-29, 2009.

[14] J. P. Silva, S. Sousa, I. Gonçalves, J. J. Porter, and S. FerreiraDias, "Modelling adsorption of acid orange 7 dye in aqueous solutions to spent brewery grains," Separation and Purification Technology, vol. 40, no. 2, pp. 163-170, 2004.

[15] G. Annadurai, R. S. Juang, and D. J. Lee, "Use of cellulosebased wastes for adsorption of dyes from aqueous solutions," Journal of Hazardous Materials, vol. 92, no. 3, pp. 263-274, 2002.

[16] C. Palma, E. Contreras, J. Urra, and M. J. Martínez, "Ecofriendly technologies based on banana peel use for the decolourization of the dyeing process wastewater," Waste and Biomass Valorization, vol. 2, no. 1, pp. 77-86, 2010.

[17] R. Sivaraj, C. Namasivayam, and K. Kadirvelu, "Orange peel as an adsorbent in the removal of Acid violet 17 (acid dye) from aqueous solutions," Waste Management, vol. 21, no. 1, pp. 105-110, 2001.

[18] F. A. Pavan, Y. Gushikem, A. C. Mazzocato, S. L. P. Dias, and E. C. Lima, "Statistical design of experiments as a tool for optimizing the batch conditions to methylene blue biosorption on yellow passion fruit and mandarin peels," Dyes and Pigments, vol. 72, no. 2, pp. 256-266, 2007.

[19] B. H. Hameed, D. K. Mahmoud, and A. L. Ahmad, "Sorption of basic dye from aqueous solution by pomelo (Citrus grandis) peel in a batch system," Colloids and Surfaces A, vol. 316, no. 1-3, pp. 78-84, 2008.

[20] S. Hamid, Z. Mahmood, M. Imran, A. Saeed, and S. R. Gillani, "Potentiality of lemon peel as low cost adsorbent for the removal of trypan blue dye from aqueous solution," Journal of the Chemical Society of Pakistan, vol. 33, no. 3, pp. 364-369, 2011.

[21] H. P. Boehm, "Some aspects of the surface chemistry of carbon blacks and other carbons," Carbon, vol. 32, no. 5, pp. 759-769, 1994.

[22] P. B. Navas and A. Carrasquero, "Cargas eléctricas supeficiales y propiedades adsorbentes del salvado de arroz," Revista Facultad Agronomía (Maracay), vol. 26, no. 2, pp. 149-161, 2000.

[23] M. A. Tshabalala, "Determination of the acid-base characteristics of lignocellulosic surfaces by inverse gas chromatography,"
Journal of Applied Polymer Science, vol. 65, no. 5, pp. 10131020, 1997.

[24] D. Mamma, E. Kourtoglou, and P. Christakopoulos, "Fungal multienzyme production on industrial by-products of the citrus-processing industry," Bioresource Technology, vol. 99, no. 7, pp. 2373-2383, 2008.

[25] X. Li, Y. Tang, X. Cao, D. Lu, F. Luo, and W. Shao, "Preparation and evaluation of orange peel cellulose adsorbents for effective removal of cadmium, zinc, cobalt and nickel," Colloids and Surfaces A, vol. 317, no. 1-3, pp. 512-521, 2008.

[26] R. K. Schofield and A. W. Taylor, "The measurement of soil pH," Soil Science Society American Proceedings, vol. 19, pp. 164-167, 1955.

[27] E. N. El Qada, S. J. Allen, and G. M. Walker, "Adsorption of basic dyes from aqueous solution onto activated carbons," Chemical Engineering Journal, vol. 135, no. 3, pp. 174-184, 2008.

[28] E. F. Jaguaribe, L. L. Medeiros, M. C. S. Barreto, and L. P. Araujo, "The performance of activated carbons from sugarcane bagasse, babassu, and coconut shells in removing residual chlorine," Brazilian Journal of Chemical Engineering, vol. 22, no. 1, pp. 41-47, 2005.

[29] C. Kaeprasit, E. Hequet, N. Abidi, and J. Gourlot, "Quality measurements: aplications of methylene blue adsorption to cotton fiber specific surface area measurement: part I. methodology," The Journal of Cotton Science, vol. 2, no. 4, pp. 164-173, 1998.

[30] H. El Bakouri, J. Morillo, J. Usero, and A. Ouassini, "Potential use of organic waste substances as an ecological technique to reduce pesticide ground water contamination," Journal of Hydrology, vol. 353, no. 3-4, pp. 335-342, 2008.

[31] I. Langmuir, "The adsorption of gases on plane surfaces of glass, mica and platinum," The Journal of the American Chemical Society, vol. 40, no. 9, pp. 1361-1403, 1918.

[32] H. Freundlich, "Of the adsorption of gases. Section II. Kinetics and energetics of gas adsorption," Transactions of the Faraday Society, vol. 28, pp. 195-201, 1932.

[33] H. Benaïssa, "Removal of acid dyes from aqueous solutions using orange peel as a sorbent material," in Proceedings of the 9th International Water Technology Conference, (IWTC9'05), p. 1175, Sharm El-sheikh, Egypt, 2005.

[34] K. V. Kumar and K. Porkodi, "Batch adsorber design for different solution volume/adsorbent mass ratios using the experimental equilibrium data with fixed solution volume/adsorbent mass ratio of malachite green onto orange peel," Dyes and Pigments, vol. 74, no. 3, pp. 590-594, 2007.

[35] V. Jaikumar, K. S. Kumar, and D. G. Prakash, "Biosorption of acid dyes using spent brewery grains: characterization and modeling," International Journal of Applied Science and Engineering, vol. 7, no. 2, pp. 115-125, 2009.

[36] A. Rodríguez, J. García, G. Ovejero, and M. Mestanza, "Adsorption of anionic and cationic dyes on activated carbon from aqueous solutions: equilibrium and kinetics," Journal of Hazardous Materials, vol. 172, no. 2-3, pp. 1311-1320, 2009.

[37] A. W. M. Ip, J. P. Barford, and G. McKay, "Reactive black dye adsorption/desorption onto different adsorbents: effect of salt, surface chemistry, pore size and surface area," Journal of Colloid and Interface Science, vol. 337, no. 1, pp. 32-38, 2009.

[38] Y. S. Ho and G. McKay, "A Comparison of chemisorption kinetic models applied to pollutant removal on various sorbents," Process Safety and Environmental Protection, vol. 76, no. 4, pp. 332-340, 1998. 

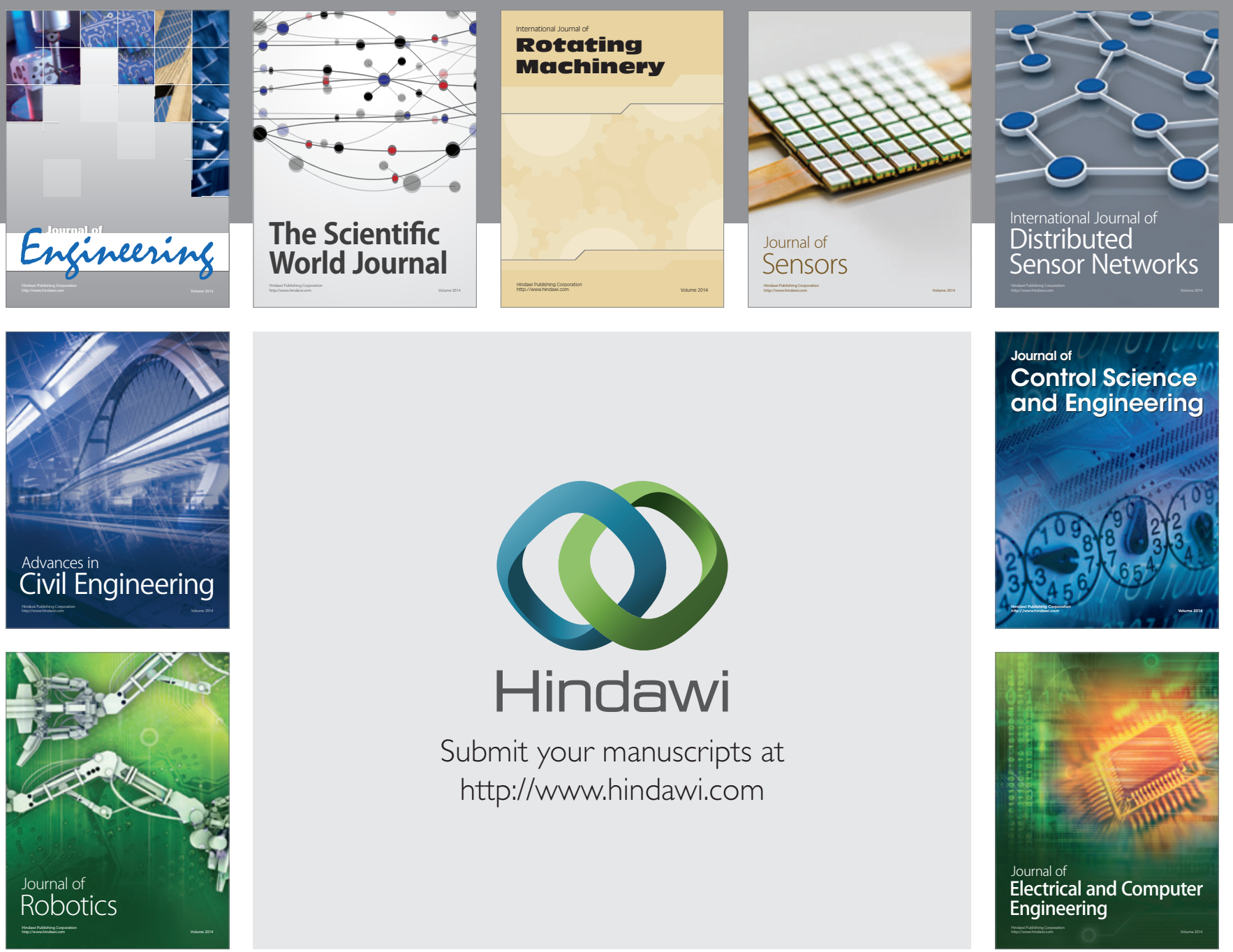

Submit your manuscripts at

http://www.hindawi.com
